\title{
A floristic comparison of three Northern Coastal Forests differing in disturbance history
}

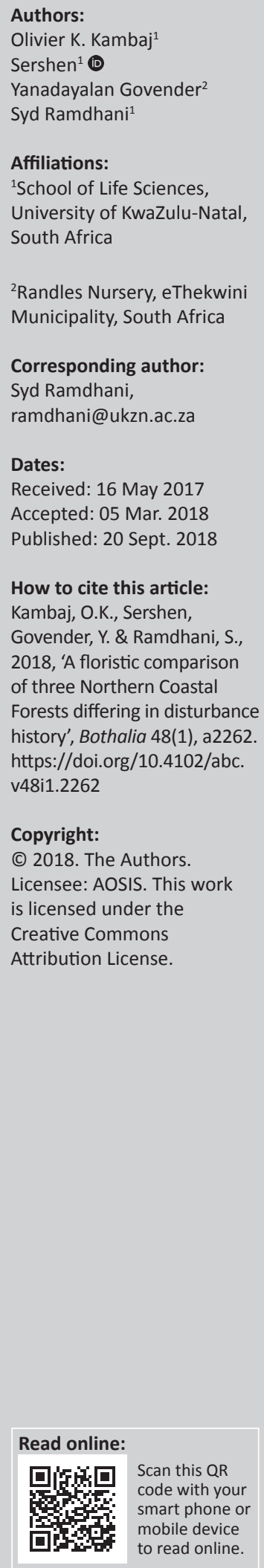

Background: The impacts of disturbance history on the floristics of Northern Coastal Forest (NCF; South Africa) are unknown.

Objectives: This study compared the floristics of three remnant patches of NCF (in KwaZuluNatal) with contrasting disturbance histories: a primary forest with low levels of disturbance (Hawaan), a primary forest with high levels of disturbance (Umdoni) and a secondary forest (Twinstreams) that was rehabilitated with presently low disturbance levels.

Method: Transects and quadrats were used to assess species composition and diversity at each site.

Results: Collectively, 688 species, 400 genera and 113 families were found, but only $21.95 \%$ of the species were shared by the three forests. The most speciose families were Fabaceae $>$ Asteraceae $>$ Rubiaceae. The species richness was highest at the disturbed primary forest and notably lower at the primary forest. Diversity indices exhibited a similar trend. Cluster analyses and ordinations indicated that the secondary forest was intermediate between the two primary forests, with the disturbed primary forest and secondary forest being more similar.

Conclusion: The disturbed and secondary forests maintained a NCF floristic affinity. The dissimilarity between Hawaan and other forests is most likely the product of differing disturbance histories and rehabilitation efforts. The findings suggested that NCF patches are likely to be different in richness, but not in structure and affinity. Anthropogenic related pressures and disturbance appear to be major causes of floristic differences amongst patches. This leads to higher levels of richness by accommodating opportunistic, atypical and alien species, and possibly the creation of novel NCF types.

\section{Introduction}

Forests are closed-canopy plant communities comprising mainly woody plants more than $5 \mathrm{~m}$ tall (Midgley et al. 1997). Forest is the smallest and most widely fragmented biome in South Africa (Low \& Rebelo 1996; Rutherford \& Westfall 1994). In South Africa, forests generally occur as patches within other biomes. It is estimated that indigenous coastal forest patches cover less than 500000 ha (Low \& Rebelo 1996). Forest along the eastern coast of South Africa represents the southernmost distribution of tropical and subtropical forest fauna and flora in Africa, and contains a high level of floristic endemism, with a number of species that are at the end of their distribution range. Indigenous coastal subtropical forest types are embedded within the broader Indian Ocean Coastal Belt (IOCB) biome (Mucina \& Geldenhuys 2006).

The narrow subtropical coastal strip of KwaZulu-Natal (KZN) contains several diverse forest types, which are patchy in distribution, but harbour relatively high biodiversity despite their limited spatial extent (Moll \& White 1978; Mucina \& Rutherford 2006). Previous studies have shown forest in KZN to have decreased in extent since the early 1800s owing to anthropogenic pressures such as agriculture, forestry, urbanisation, tourism and mining (Lawes et al. 2007; Midgley et al. 1997; Mucina \& Geldenhuys 2006). However, more recent assessments suggest that a few conserved patches of natural evergreen forest may have increased over the last 30 years (Environmental Geographic Information Systems [EGIS] 2016). This increase can be ascribed to variable combinations of the following: urban development, controlled access and protection against fire. Coastal forests in KZN typically occur as a series of small patches $(<10 \mathrm{ha}$ ) (Moll \& White 1978; Mucina \& Rutherford 2006), accounting for only approximately $9.6 \%$ of the total land area (Rutherford et al. 2006; Von Maltitz et al. 2003). Nevertheless, coastal forests in KZN still contribute to a substantial proportion of the plant biodiversity housed in the MaputalandPondoland-Albany (MPA) biodiversity hotspot (Steenkamp et al. 2004). These forests are diverse and of varying types based on vegetation composition, structure and altitude (Mucina \& 
Geldenhuys 2006), and may have been variably linked and separated owing to Quaternary glacial cycles (Griffiths \& Lawes 2006). More recent anthropogenic pressures (prior to European settlement) have also influenced the forests either directly (e.g. harvesting of wood for iron production) or indirectly (e.g. altering fire regimes) (Armstrong et al. 2000; Morgenthal \& Cilliers 1999). The most recent changes (post 1800s), which include high levels of urbanisation and agriculture, have had the most significant effects on the extent and integrity of these coastal forests. Historical transformation and conservation activities (e.g. rehabilitation and restoration) have collectively led to a mixture of primary and secondary forest types.

Forests are prone to both natural (e.g. fire, wind, temperature fluctuation, precipitation variability, alluvial processes, etc.) and anthropogenic (e.g. harvesting and burning) disturbances (Eeley, Lawes \& Piper 1999; Fahrig 2003) that can act as exogenous agents of vegetation change (White 1979). Consequently, forest flora are rich in disturbanceadapted species and disturbance-recovery processes that follow both natural and anthropogenic disturbances, contribute to floristic and structural composition, and underlie species diversity patterns in the long term (White 1979). These disturbance-recovery processes are influenced by the type, degree and duration of disturbances, as well as the natural regenerative potential of the species within the system, which includes soil seed bank composition (Bossuyt, Heyn \& Hermy 2002; Chazdon 2003). Disturbances (anthropogenic and natural) that remove large areas of tree canopies, for example, can result in excessive increases in sunlight reaching the forest floor and an associated decrease in soil moisture content. While the increased light availability can provide favourable germination conditions for lightdemanding species, the decline in soil moisture content can compromise seedling survival. Recovery following disturbances that heavily impact soils and aboveground vegetation can be considerably slow, often with long-lasting effects on species composition (Wassenaar et al. 2005).

Forest floristic composition, demography and succession stage are therefore reflections of past disturbance events and the system's ability to recover from them (Adema et al. 2005; Van Aarde \& Claassens 1998). Floristic surveys are essential for biodiversity assessment, management and conservation (Hahs et al. 2009). An appraisal of current species composition in remnant patches of coastal forest in relation to their disturbance history can therefore inform their future conservation or rehabilitation. The availability of basic coastal forest floristic data (e.g. species checklists) can also help advance broader, pressing research questions related to demography, phenology, succession, alien invasions and climate change, amongst others. This motivated the present study that compared the floristics of three Northern Coastal Forest (NCF) patches in relation to their contrasting disturbance histories.

Northern Coastal Forest (designated as FOz-7 in the forest classification developed by Mucina and Geldenhuys, 2006) is composed of two forest types, viz., KwaZulu-Natal Coastal Forest and KwaZulu-Natal Dune Forest (sensu Von Maltitz et al. 2003). In the present study, we examined KwaZulu-Natal Coastal Forest specifically, which is known to be species rich and occurs as patches within the MPA (Mucina \& Geldenhuys 2006). Studies that examine rehabilitation, restoration and regeneration of NCF or any other coastal subtropical forest types in South Africa are scarce (Olivier \& Van Aarde 2014; Van Aarde et al. 2008). The spatial, temporal, biotic and abiotic requirements for these processes to be successful are generally unknown (Arnold \& Lutzoni 2007). The three NCF patches selected for investigation here are geographically separated (by $>100 \mathrm{~km}$ ) and included Hawaan, which is largely primary forest with a small area of regrowth (c. 80 years old) that was not sampled in this study and has been subjected to low levels of disturbance and protection for c. 50 years; Umdoni, which is composed of core parts of primary forest (Mucina \& Geldenhuys 2006) and patches of new growth (10-30 years old) and has been exposed to high levels of disturbance for a prolonged period of time; and a secondary forest (Twinstreams) that was rehabilitated (partly with Sand Forest canopy tree species) (Moll \& Cooper 1966; Untiedt 1992). The disturbance and successional histories of these forests deserve further consideration and are expanded on below. At the time of this study, there were no recent published reports on floristics of the forests examined here. Previous studies conducted at Hawaan Forest (HAF) and Twinstreams Forest (TMF) (Moll 1972; Moll \& White 1978) represent a comprehensive description of the flora at that time, but are now outdated. No published data (except for an informal tree and species list) exist for Umdoni Forest (UMF).

The primary objective of the present study was to assess the impacts of disturbance on species composition and diversity in NCF. Classical vegetation survey methods were used to assess floristic composition and diversity within each forest, which was then used to assess floristic similarity amongst the three patches in relation to their contrasting disturbance histories. Important issues relate to whether a secondary forest rehabilitated with atypical species will result in these species becoming excluded from the system or successfully becoming integrated into a novel but artificial (structurally or floristically) system as reported elsewhere (Lugo \& Helmer 2004; Uriarte et al. 2009). In addition, an assessment of the similarity, in terms of species composition and diversity, between UMF (high levels of disturbance) and HAF (low levels of disturbance) allowed for an investigation of the resilience of the NCF floristic signature.

\section{Methods}

\section{Study area}

Northern Coastal Forest is found embedded in the IOCB biome that extends from the Eastern Cape northwards into KZN (Mucina \& Rutherford 2006). In some areas, these forests are restricted to the dunes (Acocks 1988). Beyond South Africa, these forests occur throughout the Mozambican coastline as far as southern Tanzania. Many tropical elements 
reach their southern limit in the NCF of South Africa (Mucina et al. 2006). The present study was conducted in three NCF patches along the Indian Ocean coastline (Figure 1). Hawaan Forest $\left(29^{\circ} 05^{\prime} \mathrm{S}, 31^{\circ} 05^{\prime} \mathrm{E}\right)$ is located in the Umhlanga Rocks area (northern Durban), while the secondary forest (TSF) $\left(30^{\circ} 23^{\prime} \mathrm{S}, 030^{\circ} 40^{\prime} \mathrm{E}\right)$ is situated near the town of Mtunzini, $160 \mathrm{~km}$ north of Durban. Umdoni Forest, the southernmost of these forests $\left(28^{\circ} 59^{\prime} \mathrm{S}, 31^{\circ} 44^{\prime} \mathrm{E}\right)$, is located between Park Rynie and Ifafa Beach. The largest forest is UMF (200 ha), followed by HAF ( $55 \mathrm{ha}$ ) and TSF (40 ha). The details of all sites are given in Table 1. To justify the comparisons made in this study, it is instructive to consider the successional status and disturbance histories of the three forests in greater detail.

A forest with no recorded logging and which has developed under natural processes following natural disturbance is considered 'primary' (Cockle, Martin \& Drever 2010). Hawaan is a primary forest that is fully fenced and access controlled for c. 50 years. A narrow fringe ( $<500 \mathrm{~m}$ wide) of secondary forest occurs along the western perimeter which is a result of this area being farmed $>80$ years ago and abandoned owing to poor soil quality. Over the course of c. 80 years, this fringe has not recovered to climax forest and is clearly distinguishable (from aerial photos and in situ) from the primary forest given the low, sparse canopy and abundance of pioneer species (e.g. Albizia adianthifolia). For the purposes of this study, we only sampled the primary forest at HAF. It should also be noted that frequent clearing of alien species has taken place at this forest for many years. In light of the sampling approach adopted here (i.e. no sampling in regrowth portions), HAF was considered a primary forest with low levels of disturbance in this study.

Umdoni is composed of core parts of primary forest (Mucina \& Geldenhuys 2006) that have experienced high levels of

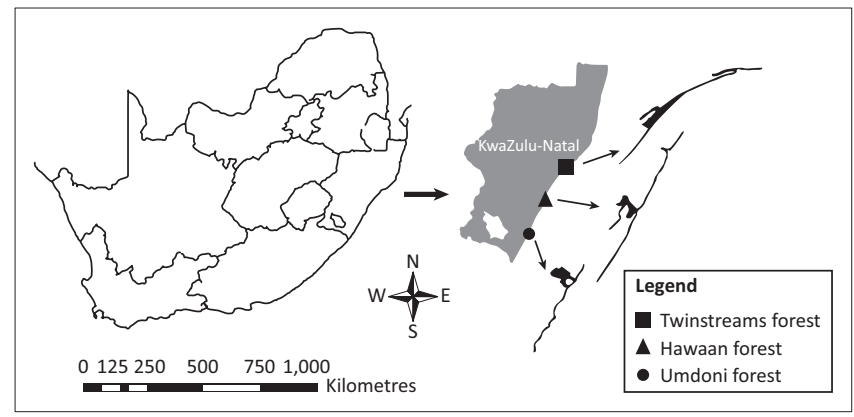

FIGURE 1: Location of the three Northern Coastal Forest study sites in KwaZulu-Natal.

TABLE 1: Summary of the features of the three Northern Coastal Forest sites.

\begin{tabular}{llll}
\hline Features & HAF & UMF & TSF \\
\hline Size (ha) & 55 & 200 & 40 \\
Altitudinal range & $20 \mathrm{~m}-140 \mathrm{~m}$ a.s.I. & $30 \mathrm{~m}-160 \mathrm{~m}$ a.s.l. & $10 \mathrm{~m}-80 \mathrm{~m}$ a.s.I. \\
Location & $\begin{array}{l}\text { Umhlanga Rocks, } \\
\text { eThekwini } \\
\text { Municipality }\end{array}$ & $\begin{array}{l}\text { Pennington, } \\
\text { Umdoni } \\
\text { Municipality }\end{array}$ & $\begin{array}{l}\text { Mtunzini, Umlalazi } \\
\text { Municipality }\end{array}$ \\
Coordinates & $29^{\circ} 05^{\prime} \mathrm{S} 31^{\circ} 05^{\prime} \mathrm{E}$ & $28^{\circ} 59^{\prime} \mathrm{S} 31^{\circ} 44^{\prime} \mathrm{E}$ & $30^{\circ} 23^{\prime} \mathrm{S} 30^{\circ} 40^{\prime} \mathrm{E}$ \\
Conservation Authority & $\mathrm{HIT}$ and UCWS & Umdoni Trust & WESSA \\
Protection & $\begin{array}{l}\text { Fenced, } \\
\text { controlled access }\end{array}$ & $\begin{array}{l}\text { Fenced, } \\
\text { controlled access }\end{array}$ & $\begin{array}{l}\text { Unfenced, } \\
\text { controlled access }\end{array}$ \\
\hline
\end{tabular}

HAF, Hawaan Forest; UMF, Umdoni Forest; TSF, Twinstreams Forest; a.s.l., above sea level; HIT, Hawaan Investments Trust; UCWS, Umhlanga Centre of the Wildlife Society; WESSA, Wildlife and Environment Society of Southern Africa. disturbance owing to the neighbouring golf course and associated activities. There are also parts of the forest that have expanded over time. These parts have been subject to uncontrolled burning and clearing, and are clearly distinguishable from the primary forest. Unlike HAF, parts of UMF are subjected to illegal access, informal pathways, clearing, illegal harvesting, erosion and only occasional alien plant removal. The anthropogenic disturbances mentioned above have not been restricted to specific parts of the forest; however, it was possible to identify the physiognomically mature part of the forest and this is the area that was sampled in the present study. With the above in place, UMF was regarded as a primary forest with high levels of disturbance.

The secondary forest (TSF) was rehabilitated from a sugar cane farm c. 70 years ago and is presently exposed to low levels of disturbance. Classical definitions of a secondary forest suggest that it is a forest that has been logged and has subsequently recovered naturally or artificially (Huang et al. 2017). The forest is presumed to be expanding out of the demarcated forest boundaries, but as in UMF, sampling at TSF was confined to the physiognomically mature part of the forest.

\section{Climate and altitude}

The coastal belt of KZN has a seasonally moist subtropical climate. Rainfall is usually in excess of $1000 \mathrm{~mm}$ per annum, becoming drier inland with less than $600 \mathrm{~mm}$ per annum (Kirkwood \& Midgley 1999; Mucina \& Rutherford 2006). The highest monthly precipitation falls between September and April, resulting in hot, humid summers and cool, dry winters. Altitude is the main factor determining both the rainfall and temperature, and ranges from $10 \mathrm{~m}$ to $160 \mathrm{~m}$ above sea level (a.s.l.) with the topography being relatively flat (Table 1). All NCFs selected in this study occur at low altitudes (10 $\mathrm{m}-160 \mathrm{~m}$ a.s.1.).

\section{Vegetation}

Floristically, coastal KZN is diverse and complex with many different vegetation types (Mucina \& Rutherford 2006; ScottShaw \& Escott 2011). More recently, all NCF patches were placed within the IOCB biome, but these forests are also a distinct vegetation type of the forest biome (Von Maltitz et al. 2003; Mucina \& Rutherford 2006). Northern Coastal Forest is described as species-rich, tall to medium-height subtropical coastal forest on coastal (rolling) plains that stabilise the sand dunes on which they occur (Moll \& White 1978; Mucina \& Rutherford 2006; Mucina et al. 2006). These forests are dense, structured into several tree layers and exhibit a well-developed shrub layer (Mucina \& Geldenhuys 2006). Interestingly, in False Bay there is Eastern Sand Forest ecotonal to what may be NCF (Kirkwood \& Midgley 1999).

\section{Data collection and analyses}

Studies investigating effects of disturbance within forests generally adopt a core to edge sampling approach (e.g. Matlack 1994) in order to compare vegetation across different parts of the same forest (intra-site comparisons). However, where the 
effects of disturbances on vegetation are to be compared across different forests (inter-site comparisons), quadrats are most often distributed across the physiognomically mature forest portions to accommodate the effects of disturbance on the system as a whole (Denslow 1995; Frelich \& Lorimer 1991; Gentry 1982). Fifteen quadrats were randomly laid out within the physiognomically mature part of the forest, more than $100 \mathrm{~m}$ apart from each other and any edge, and sampled between June 2014 and June 2015, in each of the four seasons. Quadrat sizes for forest vegetation surveys vary greatly across studies, ranging from $10 \mathrm{~m} \times 10 \mathrm{~m}$ (Matthews et al. 2001) to $50 \mathrm{~m} \times 50 \mathrm{~m}$ (Zhang \& Cao 1995) and even greater (Gentry 1982), depending on the site characteristics and research question(s). For the purpose of this study, it was imperative to reach a sampling effort of $\geq 80 \%$, irrespective of quadrat size. Given the fact that three forests had to be sampled over multiple seasons, a quadrat size of $15 \mathrm{~m} \times 15 \mathrm{~m}$ was deemed manageable and repeated sufficiently at all sites to achieve the acceptable sampling effort.

Cover (\%) and abundance were recorded for all non-graminoid taxa within each quadrat, while only cover was recorded for graminoids, given their clonal habit. To produce a comprehensive species checklist, species occurring outside of the quadrats were also recorded (but not in terms of cover and abundance) using transects once every three months (i.e. within each season). A series of ten $2 \mathrm{~m} \times 100 \mathrm{~m}$ transects were laid out in directions that avoided trails and clearings. The transects were roughly parallel to each other and separated by $20 \mathrm{~m}$ or more.

Flowering or fruiting material was collected for voucher specimens (deposited in the Ward Herbarium [UDW], University of KwaZulu-Natal). Specimens were identified in the herbarium using field guides (e.g. Boon 2010; Pooley 1998; Van Wyk \& Van Wyk 1997) and other published literature. Nomenclature and taxonomic authorships follow the New Plants of Southern Africa (New POSA) website of the South Africa National Biodiversity Institute (SANBI 2018a). The conservation status of the species was based on SANBI's Red List of South African Plants (SANBI 2018b). Checklists were compiled to include all plant species recorded in previous inventories and the present study. These lists were used to determine species composition of each forest.

Alien taxa were categorised using the National Environmental Management: Biodiversity Act (NEMBA), 2004 (Act No 10 of 2004) Alien and Invasive Species List, 2016 (Department of Environmental Affairs 2016), which includes Category 1-3 invasive aliens. Not declared aliens were determined using the Weeds and Invasive Plants website (WIP 2006). In some cases (especially naturalised exotics), the alien status was determined using SANBI (2018b). Aliens not assessed in the above literature and websites were treated as non-categorised alien taxa.

Sampling effort was based on rarefaction curves. As the number of species is highly dependent on sample size, rarefaction curves (Gotelli \& Colwell 2001) were plotted in EstimateS (Version 9.1.0) (Colwell 2013) using quadrat data of all three forests to determine whether sampling effort was sufficient (Chao et al. 2006, 2009). Graminoids (viz. grasses) were excluded from the above-mentioned analyses because abundance data for grasses were not available. Two nonparametric estimators (Chao1 and Chao2) were used to estimate total species richness. The percentage sampling effort was calculated using the number of species found in situ and the projected number of species based on the above two estimators.

The Shannon diversity $\left(H^{\prime}\right)$ and Simpson's diversity $(D)$ indices were used as measures of alpha diversity (DanoffBurg \& Xu 2008; Magurran 2004). The package PAST v3 (Paleontological Statistics) (Hammer, Harper \& Ryan 2001) was used to calculate these diversity indices based on quadrat data ( $n=15$, for each forest). Beta $(\beta)$ diversity, specifically the Whittaker's $\beta$ diversity $(\beta \mathrm{w})$ index (Flohre et al. 2011), was also compared across forests. This was computed using PAST v3 and based on quadrat data ( $n=15$, for each forest).

\section{Floristic similarity}

In the present study, cluster and ordination analyses were applied to quadrat $(n=45)$ data to assess similarity amongst the three forest sites (Albernaz et al. 2012). The presence/ absence data were used to generate a similarity matrix based on the Bray-Curtis index. Clustering was performed with the Unweighted Pair-Group Method using the Arithmetic Average (UPGMA) in PAST v3. The package PAST v3 was also used to conduct a non-metric multidimensional scaling (NMDS) ordination in two dimensions, with the Bray-Curtis index applied to quadrat abundance data $(n=45)$. The ordination was evaluated using the 'stress' value (a measure of the mismatch between instance measures and the distance in ordination space). Stress values smaller than 20 generally lead to usable interpretations (Jackson et al. 2012; Kruskal 1964). The ordination was conducted with the abundance data with default settings (two-dimensional solution, maximum number of random starts $=100$ ). Grasses were excluded from the NMDS, but not from the cluster analyses. Previous studies (e.g. Jackson et al. 2012) have adopted a similar approach. However, the groups identified by the UPGMA analysis were compared with the ordination plot to gain a better understanding of similarity amongst the study sites.

\section{Results}

\section{Sampling effort and floristics}

A total of 152, 177 and 179 species were found in quadrats at HAF (primary forest), UMF (disturbed primary forest) and TSF (secondary forest), respectively. Sampling effort based on the Chao1 and Chao2 estimators ranged from $76.7 \%$ to $83.2 \%$. Values $>80 \%$ are generally regarded as an indication of adequate sampling (e.g. Moro, De Sousa \& Matias 2012), and because the relatively high values obtained here $(76.7 \%$ 83.2\%) were based exclusively on quadrat data, this suggested that sampling was sufficient. When transect, quadrat and existing species list data were combined, the lowest number of species were found at the undisturbed primary forest (HAF; $n=312)$, followed by TSF $(n=390)$ and UMF $(n=490)$ 
(Figure 2). Collectively, 688 species belonging to 400 genera and 113 families were identified across all three forest sites, when all the data were considered (Online Appendix 1). A total of 151 species (c. $21.95 \%$ ) were common (i.e. shared) to the three forests (Figure 2). Eighty-three species were shared between the two primary forests (HAF and UMF), 24 between HAF and TSF and 95 between UMF and TSF (Figure 2). The primary forest (HAF) exhibited the lowest number of unique (i.e. unshared) taxa $(n=54)$, while 161 and 120 unique taxa were found at UMF and TSF, respectively.

The 13 most speciose families were: Fabaceae $(n=58)>$ Asteraceae $(n=48)>$ Rubiaceae $(n=39)>$ Apocynaceae $(n=28)$ $>$ Celastraceae, Poaceae $(n=27)>$ Cyperaceae $(n=24)$ $>$ Acanthaceae $(n=21)>$ Euphorbiaceae $(n=20)>$ Malvaceae $(n=17)>$ Moraceae $(n=14)>$ Rutaceae, Salicaceae $(n=13)$. These dominant families contributed to $50.73 \%$ (349 species) of the total species found across the three forests. The 14 most dominant genera in terms of species richness were: Ficus $(n=14)>$ Cyperus $(n=12)>$ Ipomoea $(n=9)>$ Gymnosporia, Senecio, Solanum $(n=8)>$ Diospyros, Helichrysum, Pavetta, Searsia $(n=7)>$ Asparagus, Eugenia, Rhoicissus, Strychnos $(n=6)$.

The dominant families (in terms of species richness) were also identified for each forest. A total of 312 species, representing 212 genera and 75 families, were found at the largely undisturbed primary forest (HAF). The 13 most species-rich families at HAF were: Rubiaceae $(n=24)>$ Fabaceae $(n=19)>$ Poaceae $(n=16)>$ Acanthaceae, Asteraceae, Rutaceae $(n=14)$ $>$ Apocynaceae, Celastraceae, Convolvulaceae, Salicaceae $(n=13)>$ Cyperaceae $(n=12)>$ Cucurbitaceae, Euphorbiaceae $(n=11)$. These 13 dominant families represent 55.45\% (173 species) of the total number of species found in this forest.

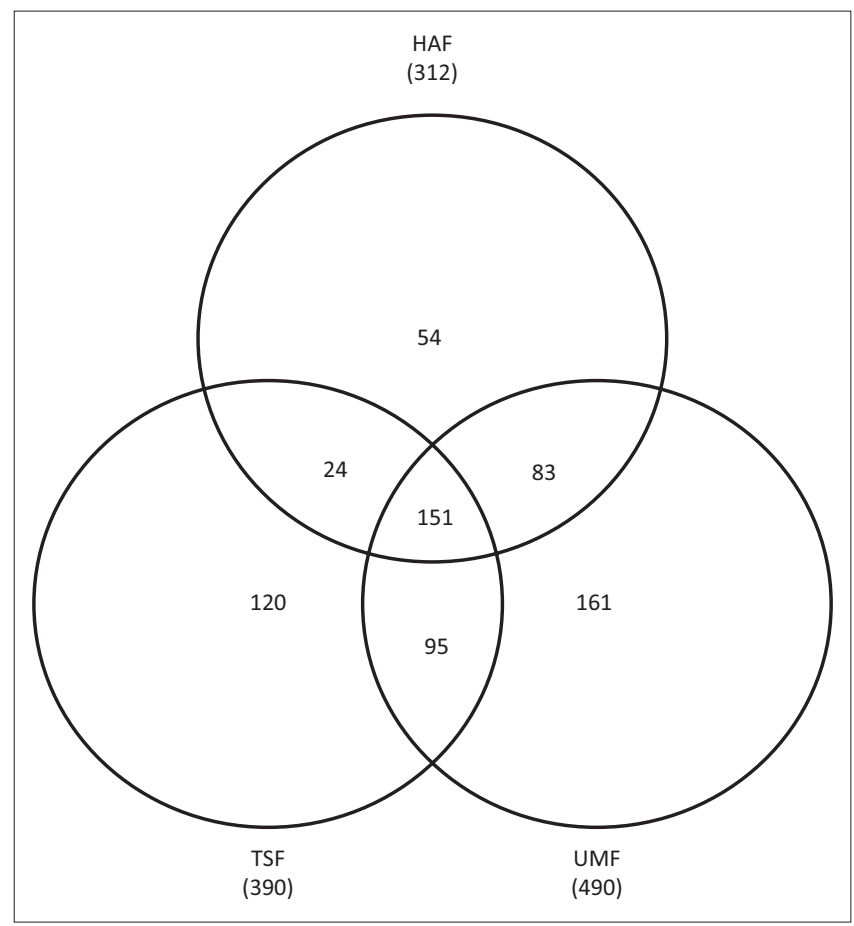

The total number of species recorded at each site is indicated in parentheses. HAF, Hawaan Forest; UMF, Umdoni Forest; TSF, Twinstreams Forest.

FIGURE 2: Venn diagram (based on quadrat, transect and species list data) showing species found within each forest site.
The disturbed primary forest (UMF) exhibited the highest number of species $(n=490)$, belonging to 315 genera and 98 families. Dominant families at UMF were: Asteraceae $(n=39)>$ Fabaceae $(n=36)>$ Rubiaceae $(n=32)>$ Apocynaceae $(n=22)>$ Poaceae $(n=20)>$ Euphorbiaceae $(n=17)>$ Acanthaceae, Celastraceae $(n=15)>$ Cyperaceae $(n=14)>$ Malvaceae $(n=12)>$ Rutaceae, Salicaceae $(n=10)$ $>$ Anacardiaceae $(n=9)$. These families contributed 251 species, $51.22 \%$ of the total number of species found at UMF.

A total of 390 species, 261 genera and 87 families were recorded at the secondary forest (TSF). The 13 most speciose families were: Fabaceae $(n=34)>$ Rubiaceae $(n=26)>$ Apocynaceae $(n=17)>$ Asteraceae $(n=16)>$ Celastraceae $(n=15)>$ Euphorbiaceae $(n=13)>$ Anacardiaceae, Poaceae $(n=12)>$ Cyperaceae, Moraceae $(n=10)>$ Acanthaceae, Malvaceae, Salicaceae $(n=9)$. These 13 families contributed 192 species $(49.23 \%)$ to the total number of species found at TSF.

It is evident that the 13 dominant families are largely common to all three forests (although ranked differently within each). Ten of the thirteen dominant families occur in the combined forest data and in individual forests (Fabaceae, Asteraceae, Rubiaceae, Euphorbiaceae, Apocynaceae, Poaceae, Celastraceae, Cyperaceae, Acanthaceae, Salicaceae) with the following exceptions (1) Malvaceae, Moraceae and Rutaceae in the combined data set, (2) Cucurbitaceae, Convolvulaceae and Rutaceae in HAF, (3) Anacardiaceae, Malvaceae and Rutaceae in UMF and (4) Anacardiaceae, Malvaceae and Moraceae and in TSF. However, there were unshared representations at family level in all of the forests: Dennstaedtiaceae and Malpighiaceae occurred at HAF only; Balsaminaceae, Brassicaceae, Campanulaceae, Cannaceae, Caryophyllaceae, Casuarinaceae, Cupressaceae, Cycadaceae, Goodeniaceae, Lobeliaceae, Melostomataceae, Myrsinaceae, Nymphaeaceae, Oliniaceae, Orobanchaceae, Rosaceae and Thelypteridaceae occurred at UMF only; while Aizoaceae, Basellaceae, Blechnaceae, Lecythidaceae, Maesaceae, Myricaceae, Nephrolepidaceae, Piperaceae, Plumbaginaceae, Violaceae and Zingerberaceae only occurred at TSF.

\section{Taxa of conservation concern}

Twenty-eight species $(4.07 \%$ of the total number of species found across the three forests) are of conservation concern: seven Endangered, nine Vulnerable, seven Near Threatened, two Rare and three Declining (Table 2). The lowest number of species of conservation concern occurred at HAF $(n=8)$, while TSF and UMF had 17 and 18 of these species, respectively. The species of conservation concern were classified according to the SANBI National Red List (SANBI 2018b), which provides fairly detailed information on species habitats and vegetation types. All 28 species of conservation concern occur across more than one vegetation, but only 12 of these are considered typical forest elements (Table 2). Only three species of conservation concern were common to all forests: Dioscorea sylvatica (Vulnerable), Atalaya natalensis (Near Threatened) and Adenia gummifera 
TABLE 2: Taxa of conservation concern found in the three Northern Coastal Forest sites.

\begin{tabular}{|c|c|c|c|c|c|}
\hline Species & Family & Conservation status & HAF & UMF & TSF \\
\hline Eugenia umtamvunensis & Myrtaceae & Endangered & - & - & $x$ \\
\hline Gymnosporia woodii & Celastraceae & Endangered & - & $x$ & $x$ \\
\hline Lydenburgia abbottii & Celastraceae & Endangered & $x$ & - & - \\
\hline Manilkara nicholsonii & Sapotaceae & Endangered & - & $x$ & - \\
\hline Maytenus abbottii & Celastraceae & Endangered & - & - & $\mathrm{x}$ \\
\hline Mondia whitei & Apocynaceae & Endangered & - & $x$ & $x$ \\
\hline Calpurnia woodii & Fabaceae & Vulnerable & $x$ & $x$ & - \\
\hline Cassipourea gummiflua & Rhizophoraceae & Vulnerable & - & $x$ & $x$ \\
\hline Colubrina nicholsonii & Rhamnaceae & Vulnerable & - & $x$ & - \\
\hline Cryptocarya myrtifolia & Lauraceae & Vulnerable & - & $x$ & $\mathrm{x}$ \\
\hline Dioscorea brownii & Dioscoreaceae & Vulnerable & - & $x$ & - \\
\hline Dioscorea sylvatica & Dioscoreaceae & Vulnerable & $x$ & $x$ & $x$ \\
\hline Eugenia simii & Myrtaceae & Vulnerable & - & $x$ & - \\
\hline Stangeria eriopus & Stangeriaceae & Vulnerable & - & $x$ & - \\
\hline Aloe thraskii & Asphodelaceae & Near Threatened & - & - & $x$ \\
\hline Atalaya natalensis & Sapindaceae & Near Threatened & $x$ & $x$ & $x$ \\
\hline Cryptocarya wyliei & Lauraceae & Near Threatened & - & $x$ & - \\
\hline Elaeodendron transvaalense $e^{\mathrm{SFE}}$ & Celastraceae & Near Threatened & - & - & $x$ \\
\hline Encephalartos natalensis & Zamiaceae & Near Threatened & - & $x$ & $x$ \\
\hline Erythrophleum lasianthum ${ }^{\mathrm{SFE}}$ & Fabaceae & Near Threatened & - & - & $x$ \\
\hline Putterlickia retrospinosa & Celastraceae & Near Threatened & $x$ & $x$ & - \\
\hline Crassula sarmentosa & Crassulaceae & Rare & $\mathrm{x}$ & - & - \\
\hline Gymnosporia devenishii & Celastraceae & Rare & - & - & $x$ \\
\hline Adenia gummifera & Passifloraceae & Declining & $x$ & $x$ & $x$ \\
\hline Cassipourea malosana & Rhizophoraceae & Declining & $x$ & $x$ & - \\
\hline Cryptocarya latifolia & Lauraceae & Declining & - & $\mathrm{x}$ & $\mathrm{x}$ \\
\hline
\end{tabular}

Note: The cross mark ' $X$ ' denotes the presence of the species in the forest while dash ' - ' denotes absence.

HAF, Hawaan Forest; UMF, Umdoni Forest; TSF, Twinstreams Forest; ${ }^{\text {SFE, }}$ Sand Forest Element.

(declining). Hawaan Forest and TSF shared no taxa of conservation concern, while HAF and UMF shared three species of conservation concern. Twinstreams Forest and UMF shared six species of conservation concern (Table 2).

\section{Alien taxa}

Alien taxa accounted for $8.72 \%$ (60 species) of the total number of species identified across the three forests (Online Appendix 2). These included Category 1-3 aliens (Category 1 $[n=31]$, Category $2[n=3]$, Category $3[n=2])$, followed by not declared aliens $(n=8)$, naturalised exotics $(n=9)$ and non-categorised aliens $(n=7)$. In summary, there were 36 Category 1-3 aliens which are considered as invasive alien plant species (IAPs). The highest number of aliens were found in the disturbed primary forest $(n=43)$, followed by the secondary forest $(n=30)$. The primary relatively undisturbed forest (HAF) housed far fewer aliens $(n=17)$. A few aliens (e.g. Chromolaena odorata, Lantana camara, Litsea sebifera, Rivina humilis, Solanum seaforthianum, Achyranthes aspera and Carex sylvatica) were present in all three forests. Nine alien species were shared between the disturbed primary forest and the secondary forest, three between the two primary forests and just four between HAF and TSF (Online Appendix 2).

\section{Diversity indices}

The Shannon's evenness index was comparable across the three forests: $0.87,0.80$ and 0.86 for HAF, UMF and TSF,
TABLE 3: Species richness and various diversity indices of the three Northern Coastal Forest sites (all diversity indices based on quadrat data).

\begin{tabular}{lccc}
\hline Variables & $\begin{array}{c}\text { Hawaan } \\
\text { Forest }\end{array}$ & $\begin{array}{c}\text { Umdoni } \\
\text { Forest }\end{array}$ & $\begin{array}{c}\text { Twinstreams } \\
\text { Forest }\end{array}$ \\
\hline Total species richness recorded in quadrats & 152 & 177 & 179 \\
Range of number of species per quadrat & $49-55$ & $44-56$ & $43-52$ \\
Shannon evenness index & 0.87 & 0.80 & 0.86 \\
Shannon diversity index $\left(H^{\prime}\right)$ & 4.37 & 3.69 & 3.79 \\
Simpson's index $D$ & 0.017 & 0.024 & 0.022 \\
Simpson's index of diversity (1-D) & 0.983 & 0.976 & 0.978 \\
Whittaker $\beta$ diversity & 1.84 & 2.65 & 2.38 \\
\hline
\end{tabular}

respectively (Table 3). These results suggest that all three forests have equivalent evenness. The Shannon diversity $\left(H^{\prime}\right)$ index did, however, differ across forests, with values being highest for the primary forest (4.37), followed by the secondary forest (3.79) and disturbed primary forest (3.69). The Simpson's index of diversity $(1-D)$ was almost the same for all three forests. Whittaker's $\beta$ diversity $(\beta \mathrm{w})$ index was highest for the disturbed primary forests (2.65), followed by the secondary forest (2.38), and relatively lower in the primary forest (1.84) (Table 3).

\section{Floristic similarity}

The phenogram of the UPGMA analysis shown in Figure 3 was based on the presence/absence data of 282 species (including grasses) found in the quadrats. There are three main clusters (A-C) at c. $20 \%$ similarity. Clusters A, B and C are composed of quadrats from HAF, TSF and UMF, respectively. Each cluster is forest specific, that is, contains 


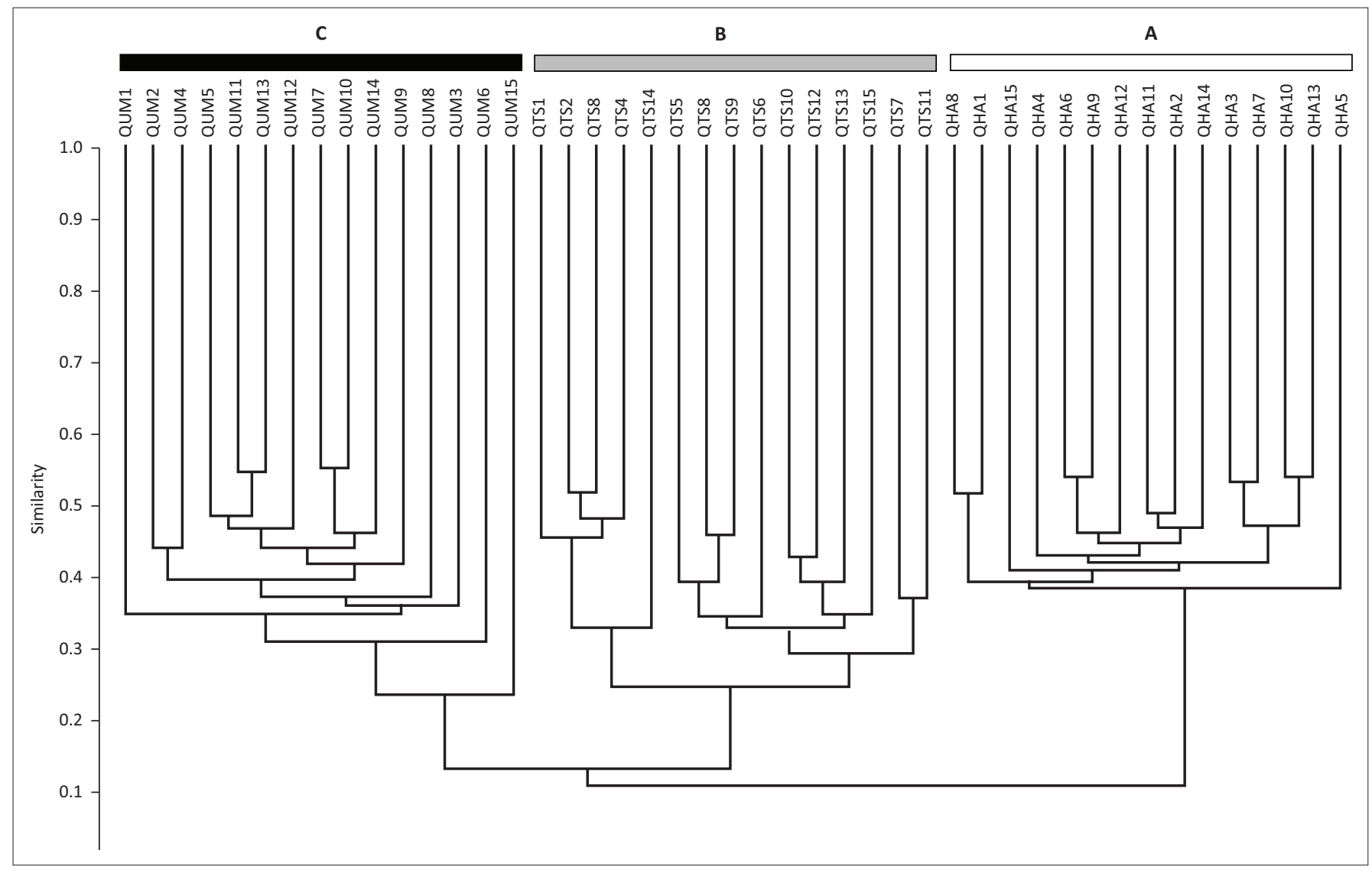

FIGURE 3: Phenogram generated from the Unweighted Pair-Group Method using the Arithmetic Average analyses of the three sites (45 quadrats). The letters (A-C) and the coloured bars denote the three Northern Coastal Forest study sites (A, white $=$ Hawaan Forest [HAF]; B, grey = Twinstreams Forest [TSF]; C, black = Umdoni Forest [UMF]).

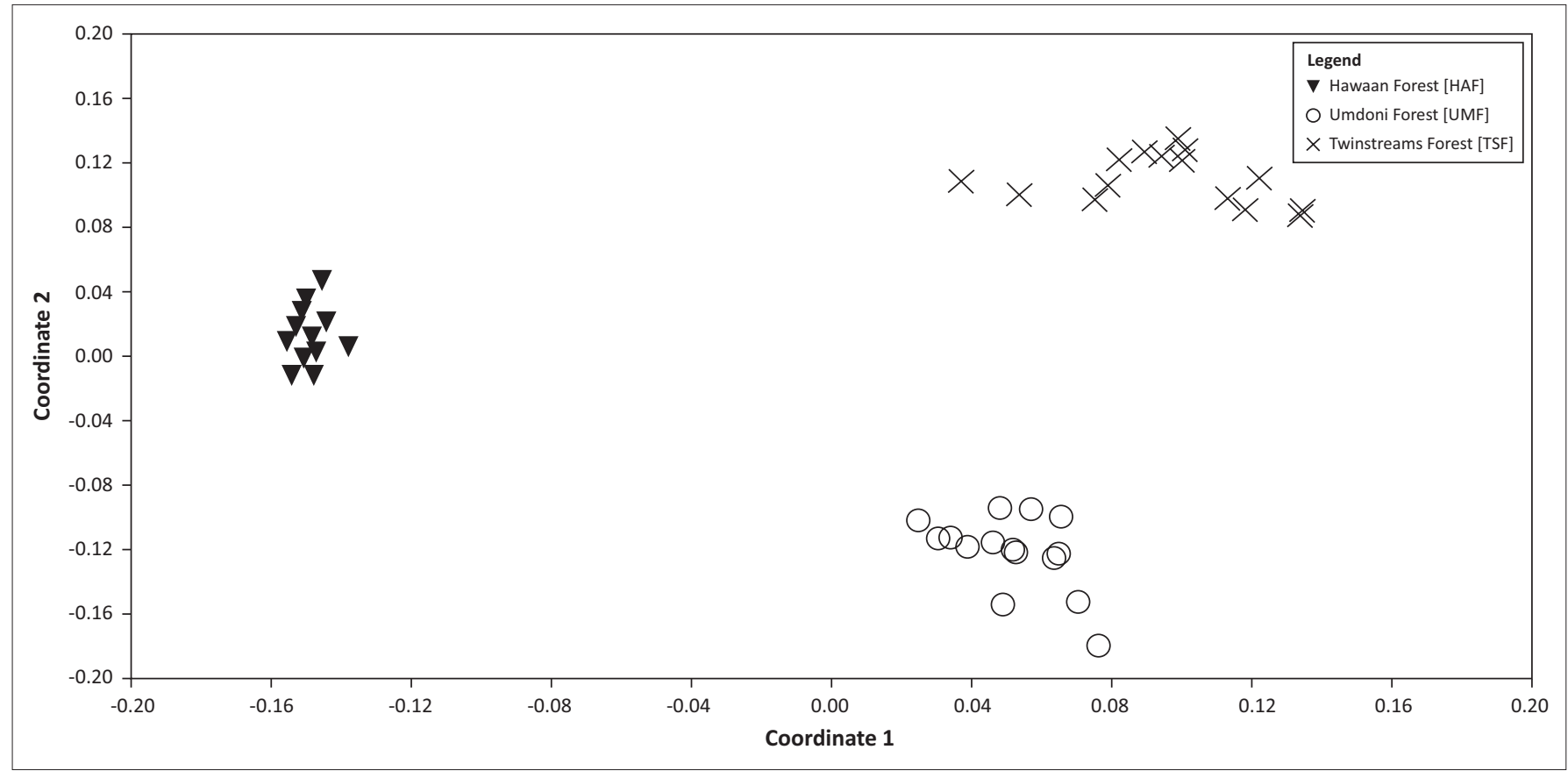

FIGURE 4: Non-parametric multidimensional scaling ordination plot of the three study sites.

quadrats from a single forest site only. Clusters B and C grouped together, indicating that the disturbed primary forest (UMF) and secondary forest (TSF) are more similar to each other than to Cluster A, the primary forest (HAF). Furthermore, it is worth noting that the two primary forests are geographically more proximal to each other than either are to the secondary forest (TSF).

The NMDS analyses showed a separation of three forest specific groups with low similarity (Figure 4). The primary 
forest (HAF) was clearly separated from (i.e. dissimilar to) the other two forests along axis 1 in the ordination space (stress $=22.97$ ). These results suggest that UMF and TSF are more similar to each other than either are to HAF, a pattern also found in the UPGMA analysis above. These results are assumed to reflect the differences in species composition and abundances of the three forests.

\section{Discussion}

\section{Sampling approach}

Some studies assessing the effects of disturbance on forests have sampled along a disturbance gradient (e.g. Matlack 1994), from core to edge, within individual forests. The major advantage of this approach is that it allows one to assess the effects of disturbance within parts of the same system. However, differences in species composition arising from core to edge sampling are largely a reflection of differences in vegetation age. Disturbances such as illegal harvesting and tree felling, and even natural disturbances, are also not confined to the edge. In fact, our observations suggest that in many forest patches this occurs within the core of the forest. In addition, dispersers, plant propagules and alien plants move freely between disturbed and undisturbed portions of the same forest, making it a very fluid system. For these reasons, core to edge sampling may not allow one to assess the effects of disturbance on the system as a whole. Randomly positioning quadrats within the physiognomically mature part of the forest is a common approach when examining disturbance effects on forests (e.g. Denslow 1995; Frelich \& Lorimer 1991) and may be an alternative way to capture heterogeneous distribution of disturbances within forests. Furthermore, this approach facilitates floristic comparisons across different forests.

\section{Floristic composition and structure}

Studies on other tropical and subtropical forests have shown species richness and diversity to be influenced by a range of biotic (e.g. competition, regeneration, growth, migration and succession [Newbold et al. 2014; Whittaker, Willis \& Field 2001]) and abiotic (e.g. temperature, humidity, precipitation and soil moisture [Arnold \& Lutzoni 2007; Pimm et al. 2014]) factors. In lowland coastal forests of $\mathrm{KZN}$, succession can occur rapidly (30-40 years), and large-scale natural disturbances (e.g. periodic fires and herbivory) are essential for forest processes (Van Wyk et al. 1996). However, these coastal forests (including NCF) are also subjected to anthropogenic related pressures and disturbances (e.g. urban development, fragmentation, pollution and mining [Midgley et al. 1997]). Of the three forests compared here, the primary forest (HAF) has received the best protection over the last 50 years and has been maintained in a relatively undisturbed state (except for some parts of its margin) through fencing, controlled access and alien plant control. The disturbed primary forest (UMF) and the secondary forest (TSF) have more recently received some protection, but both are still open to human disturbance owing to poor controlled access and protective measures. Furthermore, as mentioned earlier,
TSF is a secondary forest that was rehabilitated using a number of Sand Forest taxa.

When the quadrat data were considered, the number of species found in the three forests (152-179) was in the range reported for subtropical forests in eastern KZN (e.g. 104 woody species [Gaugris \& Van Rooyen 2008]); 195 tree species [Griffiths \& Lawes 2006]). However, the number of species was lowest in the primary forest (HAF) and comparably higher in UMF and TSF, despite the latter being a secondary forest. When the quadrat data were supplemented with transect and existing species list data, the total number of species was again lowest in the undisturbed primary forest (HAF; $n=312$ ) and higher in the secondary forest (TSF; $n=390$ ) and disturbed primary forest (UMF; $n=490$ ) (Figure 2). It was expected that UMF would have the highest species richness based on size (200 ha) (MacArthur \& Wilson 1967). However, TSF, the smallest forest (40 ha), had far more species than HAF (55 ha) (Table 1). As in other studies (e.g. Pimm et al. 2014), these data suggest that habitat loss and disturbance influence forest species richness (i.e. alpha diversity). Studies on forests in others parts of the world have also shown that certain disturbances can lead to an increase in forest alpha diversity (Hobbs et al. 2006; Macdonald et al. 1989).

Despite the differences in alpha diversity noted above, the three forest patches exhibited a number of similarities in terms of dominant families. For instance, Fabaceae was the most species-rich family in TSF and ranked second in HAF and UMF (where Rubiaceae and Asteraceae were the most speciose families, respectively). The dominance of Fabaceae (8.58\% of the total flora found) in all three forests is not surprising as it is amongst the most important subtropical forest families (Terborgh \& Andresen 1998). Northern Coastal Forest is known to have nutrient-deficient, sandy soil substrates (Ceruti 1999) and legumes are particularly successful on nutrient-poor substrates (Dickinson 2003) owing to their ability to fix atmospheric nitrogen, and produce large seeds, which provides them with an advantage (Ter Steege et al. 2006).

Furthermore, the 13 most dominant families ( $\geq 13$ species) in this study comprised 349 species (50.73\% of the total flora). Nine of these families are considered large Angiosperm families (Fabaceae, Asteraceae, Rubiaceae, Euphorbiaceae, Apocynaceae, Poaceae, Cyperaceae, Malvaceae and Acanthaceae) that have $\geq 4000$ species globally (Angiosperm Phylogeny Website [APW], 2018). These families are always highly placed in global rankings of large Angiosperm families (e.g. APW 2018; Good 1974). The remaining four families (Celastraceae, Rutaceae, Salicaceae and Moraceae) are represented by c. 1100-2085 species globally (APW 2018). Orchidaceae, which is one of the largest Angiosperm families with c. 26000 species globally (APW 2018), was poorly represented in this study (10 species, Online Appendix 1). Some epiphytic orchids (e.g. Cyrtorchis arcuata, Cyrtorchis praetermissa and Mystacidium capense) were recorded, but those which reside in the upper reaches of the canopy may 
have been overlooked in the quadrat sampling. The dominant families mentioned above are also well represented in the South African flora in general (Van Wyk \& Smith 2001).

The Shannon's evenness index was comparable across the three forests irrespective of disturbance history. A threshold value of 2 for the Shannon diversity $\left(H^{\prime}\right)$ index is considered as a minimum value, above which an ecosystem may be regarded as having medium to high diversity (Whittaker 1972). Values for this index for all forests studied were higher than 2 and in the range of values reported for other KZN coastal forests (2.3-3.6 [Olivier \& Van Aarde 2014]). Interestingly, values for this index were highest for the primary forest (4.37), followed by the secondary forest (3.79) and disturbed primary forest (3.69). Values for the Simpson's index of diversity index (1-D) obtained here were slightly higher than that reported for KZN coastal forests (0.58-0.88 [Olivier \& Van Aarde 2014]). Unlike species richness, diversity indices take into account species abundance as well. Despite this, the patterns observed for diversity appear to contradict those observed for species richness generated for each forest via the compilation of quadrat, transect and species lists, which showed species richness to be the greatest in the secondary forest and lowest in the primary forest (Figure 2). A comparison of the quadrat data exclusively also showed species richness to be the lowest at $\operatorname{HAF}(n=152)$ and higher at both UMF $(n=177)$ and TSF $(n=179)$ (Table 3$)$.

This contradiction may be a manifestation of a disturbanceinduced increase in species richness at UMF and TSF. Disturbances associated with anthropogenic activities were notably higher at UMF and TSF (Kambaj, Sershen \& Ramdhani 2016), which could have accommodated opportunistic species and, hence, increased richness as reported for forests elsewhere (Gibson et al. 2011; Macdonald et al. 1989). The explanation offered above is supported by the fact that alien plant species in UMF and TSF were higher than that in HAF. These aliens are known to be disturbance opportunists (Richardson et al. 2005), which contributed to the higher species richness within the disturbed forests. It is also worth noting that the secondary and disturbed primary forest exhibited higher numbers of unique species (121 and 161, respectively) than the primary forest (54) (Figure 2). The low number of unique flora, together with the relatively lower species richness at this forest, suggests that high levels of protection in HAF may have facilitated higher levels of stability (despite its size) compared with the disturbed patches. A number of unique species in the disturbed forests were also abundant (e.g. Tricalysia lanceolata and Oricia bachmannii in UMF; Microsorum scolopendria and Millettia grandis in TSF [data not shown]) and included aliens (Ageratum houstonianum, Rubus apetalus and Solanum mauritianum in UMF; Mangifera indica in TSF) as well as taxa of conservation concern (Ocotea bullata in TSF; Cryptocarya latifolia in UMF).

In addition to the above, $\beta \mathrm{w}$ values for the three forests (1.84 for HAF; 2.65 for UMF; and 2.38 for TSF; Table 3) suggest that these sites are dissimilar. Beta diversity is the spatial turnover or change in the identities of species. It measures the difference in species composition either between two or more local assemblages or between local and regional assemblages (Koleff, Gaston \& Lennon 2003). A $\beta \mathrm{w}$ of 0 indicates that sample units have all the same species, while a high $\beta$ w value indicates the opposite (Whittaker 1972). These results are supported by the fact that of the 688 species collectively found across all three forests, only $21.95 \%$ were shared by all three forests (Figure 2), with HAF sharing only 24 species with TSF. As alluded to earlier, high $\beta \mathrm{w}$ at UMF and TSF may be related to the disturbance and rehabilitation history of these two sites.

A shortcoming of the present study is that data on stem density and diameter data were not collected. These data would have allowed us to relate differences in species composition and diversity across the three forests to possible differences in vegetation age. Studies have shown species richness to be significantly correlated with stem density (Denslow 1995). However, Denslow (1995) also showed that the wellestablished relationship between abundance and diversity offers a suitable null model for the effects of disturbances on forest tree species diversity. Species abundance data were collected in the present study and differences in species composition and abundance across the three forests are possibly the product of variable combinations of disturbance, rehabilitation, protection and natural succession. Twinstreams Forest, for example, housed several species that are atypical of NCF and Sand Forest elements (e.g. Elaeodendron transvaalense and Newtonia hildebrandtii) (Boon 2010). In addition, Ocotea bullata and Sterculia murex were recorded in TSF. Ocotea bullata is a mist-belt forest element, while S. murex is naturally distributed in northern Swaziland and Mpumalanga province (Boon 2010). Their presence and more importantly persistence at TSF is based on the fact that this patch of NCF was reforested with Sand Forest and other elements.

The cluster analysis and NMDS plot reflect the site differences described above. Quadrats of TSF and UMF are placed closer, while HAF quadrats were more dissimilar to those of the disturbed sites (Figure 4). It is generally expected that fragmented landscape patches closer in geographic proximity have similar species compositions, that is, they are more similar (MacArthur \& Wilson 1967). Similarities amongst forest patches have in the past been attributed to the regional species pool being subjected to the same selection pressures during glacial maxima (Griffiths \& Lawes 2006). Species characteristic of NCF (Gaugris \& Van Rooyen 2008; Mucina \& Geldenhuys 2006) were present in both primary forests (e.g. Allophylus natalensis, Brachylaena discolour, Crotalaria natalensis, Dracaena aletriformis, Drypetes arguta, Ficus natalensis, Harpephyllum caffrum, Protorhus longifolia, Teclea natalensis and Zanthoxylum capense) and also in the secondary forest (TSF). However, HAF and UMF, which are closer in geographic proximity to each other, than either are to TSF, did not cluster together. An ecosystem's stability is based on two separate but interrelated properties: resistance and resilience (Lehman \& Tilman 2000). Resilience refers to the speed of recovery from disturbance, while resistance is associated with an ecosystem's ability to retain structure and 
composition following a perturbation and/or to regenerate. The comparisons of the floristics between a primary forest (HAF) and primary disturbed (UMF) forest conducted here suggest that certain elements of the NCF signature may be more resistant to disturbance than others.

Disturbance and the presence of Sand Forest and other elements in TSF could account for its intermediate positioning in the ordination and suggest that TSF (and UMF to some extent) may represent novel ecosystems in which disturbance (and rehabilitation) has facilitated the introduction of species outside the NCF floristic signature. However, these disturbances and the introduction of new species have not led to a change in vegetation structure and exclusion of typical NCF taxa. Human disturbances can drastically affect ecosystem trajectories, and, in changing species composition and relative abundance, can create 'novel ecosystems', commonly referred to as 'emerging ecosystems' (Hobbs, Higgs \& Harris 2009; Pimm et al. 2014). Novel or emerging ecosystems have not been reported for NCF previously, but have been reported for other forest types (Milberg \& Lamont 1995). Communities that develop on these modified patches are generally persistent and characterised by new species combinations (e.g. Milberg \& Lamont 1995), which may be the case at TSF (and UMF).

\section{Conservation of Northern Coastal Forest}

Northern Coastal Forests fall within the MPA biodiversity hotspot (Steenkamp et al. 2004), contributing to its richness and endemism. There are strong indications that NCF has harboured species of tropical forest origin (e.g. Baphia racemosa, Celtis africana, Cola natalensis and Vepris lanceolata) (Kirkwood \& Midgley 1999; Moll \& Cooper 1966) for most of its history, forming a relatively stable vegetation type in which extinction levels have been relatively low (Olivier \& Van Aarde 2014). However, NCF is presently fragmented in eastern $\mathrm{KZN}$ and is under anthropogenic pressure and disturbance (from agriculture, illegal clearing, unsustainable harvesting of medicinal plants and alien plant invasions [Von Maltitz et al. 2003]) in various coastal urban matrices where remnant patches still occur (Mucina et al. 2006). These forests are naturally fragmented even without human influence. However, anthropogenic disturbances related to the built environment prevent expansion and reconnection as is the case in HAF, which is surrounded almost entirely by urban development. A few patches of NCF may be expanding (e.g. Twinstreams [Authors unpubl. observ.]), but the nature and extent are uncertain and require quantitative confirmation.

Conserving biodiversity in areas of high human density or activity is a major conservation challenge (Dearborn \& Kark 2010). This is particularly apparent along the KZN coastline, where large-scale habitat transformation has led to the loss of approximately 50\% of native vegetation (Midgley et al. 1997). Northern Coastal Forest presently faces a number of threats, particularly on coastal dunes (Olivier \& Van Aarde 2014). Research conducted in the late 1990s indicated that anthropogenic activities led to the expansion of IAPs, which have, in turn, had negative effects on coastal $\mathrm{KZN}$ vegetation (Midgley et al. 1997). However, more recent studies have shown that facilitative interactions between IAPs and native species occur in a wide range of habitats, including forests (Rodriguez 2006). According to Rodriguez (2006), habitat modification (e.g. shading) is most often the mechanism through which IAPs aid the emergence and subsequent growth of native species, but a combination of different mechanisms (trophic subsidy, pollination, competitive release, predatory release, etc.) can also apply. This implies that IAPs may facilitate expansion of the forests investigated here, but this would require a focused study on alien-native plant interactions along forest edges. This was beyond the scope of the present study, but certainly a recommendation for future studies, given reports that the facilitative effects of alien species can aid forest restoration efforts by modifying habitats and promoting the establishment of native species (D'Antonio \& Meyerson 2002). It should be noted, however, that a high number of IAPs were present within mature parts of all three forests investigated, including the one with low levels of disturbance (HAF). These species included Category 1-3 IAPs (Online Appendix 2), many of which are significant invaders in South Africa (Nel et al. 2004). Studies have shown that the general assumption that undisturbed forests are highly resistant to plant invasions may not hold under all circumstances; for example, 139 exotic plant species have been shown to invade relatively undisturbed deeply shaded forest understories (Martin, Canham \& Marks 2009). These authors go on to state why exotics present a unique management challenge: (1) exotics often increase in abundance during succession; (2) their invasion rate may be comparatively slow under natural disturbance regimes; (3) their rate of invasion may be accelerated by anthropogenic processes, including the spread of exotic pests and pathogens. Many IAPs were reported to be prominent in NCFs as far back as 1985 (Cooper 1985) and our results suggest that many of these aliens have persisted while new ones have also emerged.

It was encouraging to note that several species of conservation concern were still present in the patches investigated. All 28 species of conservation concern occur across more than one vegetation type, while only 12 of these are considered typical forest elements (SANBI 2018b), which suggests that these species are not confined to NCF, but also occur in adjacent coastal vegetation types. The lack of species of conservation concern should reflect disturbance (i.e. fewer species of conservation concern in increasingly disturbed sites). However, in the present study, the lowest number of species of conservation concern occurred at the forest with the lowest levels of disturbance (HAF; $n=8$ ). The high number of such species in TSF $(n=17)$ may be explained by the deliberate planting of these species during rehabilitation. The relatively large size of UMF (200 ha) could explain why it housed the highest number of species of conservation concern $(n=18)$. Endangered species were most prevalent (in terms of the number of species) in TSF followed by UMF and HAF, while UMF harboured the most Vulnerable and Declining species. Near Threatened species were also most prevalent in TSF, 
followed by UMF and HAF. An equal number of rare species were found in HAF and TSF, with UMF having no rare species.

These results emphasise the conservation value of both undisturbed and disturbed NCF patches, the benefits of rehabilitating transformed patches and the need to increase levels of protection within disturbed patches. The success of conservation plans for these NCF patches and other forests that occur within urban matrices depends on the combined and coordinated efforts of researchers, land owners, corporates, government, local communities and non-governmental stakeholders (Kambaj, Sershen \& Ramdhani 2016).

\section{Conclusion}

The comparison of three NCF patches differing in disturbance history carried out here suggests that these forests all exhibit high levels of alpha and beta diversities. Disturbance and rehabilitation in the case of TSF has led to differences in both alpha and beta diversities across the forests, with the primary forest composition being distinct from the two disturbed forests. Disturbance and/or rehabilitation has also led to the presence of species atypical of NCF, many of which are aliens. Nevertheless, the patches shared some similarities in species composition and physical structure, and a number of typical NCF taxa have persisted in all three forests. This together with the high number of species of conservation concern within all three patches emphasises their conservation value. Most importantly, the results suggest that even though disturbance and rehabilitation of NCF can lead to the creation of novel ecosystems, NCF signature taxa occurred at both the disturbed and restored sites.

\section{Acknowledgements}

O.K.K. thanks the National Research Foundation (NRF) for a study grant (Grant number 89267). The authors are grateful for the help from Langelihle L. Shange and others who assisted in the field, and forest managers and land owners who kindly allowed and facilitated this research. The authors also thank Jocelyn Sutherland (Hawaan Forest Management), Tongaat Hulett Sugar, Rynardt Crous (Umdoni Trust) and Steve Untiedt (Wildlife and Environment Society of Southern Africa [WESSA], Twinstreams). Tyran Murugan assisted with designing the maps. S.R. thanks the University of KwaZuluNatal for research support. S. thanks the NRF Thuthuka Program for funding.

\section{Competing interests}

The authors declare that they have no financial or personal relationships that may have inappropriately influenced them in writing this article.

\section{Authors' contributions}

O.K.K., S. and S.R. conceived the idea and led the writing. O.K.K., T.G. and S.R. identified the plants and conducted field work. O.K.K. and S.R. analysed the data. O.K.K. led most of the writing with contributions from the other authors.

\section{References}

Acocks, J., 1988, Veld types of South Africa, Botanical Research Institute, Pretoria, South Africa.

Adema, E.B., Van de Koppel, J., Meijer, H.A. \& Grootjans, A.P., 2005, ‘Enhanced nitrogen loss may explain alternative stable states in dune slack succession', Oikos 109 374-386. https://doi.org/10.1111/j.0030-1299.2005.13339.x

Albernaz, A.L., Pressey, R.L., Costa, L.R., Moreira, M.P., Ramos, J.F., Assuncao, P.A et al., 2012, 'Tree species compositional change and conservation implications in the white-water flooded forests of the Brazilian Amazon', Journal of Biogeography 39, 869-883. https://doi.org/10.1111/j.1365-2699.2011.02640.x

Angiosperm Phylogeny Website (APW), 2018, Angiosperm Phylogeny Website, viewed 17 June 2018, from http://www.mobot.org/MOBOT/research/APweb/

Armstrong, A., Benn, G., Coke, M., Goodman, P., Johnson, D., Langley, D. et al., 2000, Determining the conservation value of land in KwaZulu-Natal, Biodiversity Division, KwaZulu-Natal Nature Conservation Services, Department of Water Affairs and Forestry Report, Pretoria, South Africa.

Arnold, A.E. \& Lutzoni, F., 2007, 'Diversity and host range of foliar fungal endophytes: Are tropical leaves biodiversity hotspots?', Ecology 88, 541-549. https://doi.org/ 10.1890/05-1459

Boon, R., 2010, Pooley's trees of eastern South Africa, Flora and Fauna Publications Trust, Durban.

Bossuyt, B., Heyn, M. \& Hermy, M., 2002, 'Seed bank and vegetation composition of forest stands of varying age in central Belgium: Consequences for regeneration of ancient forest vegetation', Plant Ecology 162, 33-48. https://doi.org/10.1023/ A:1020391430072

Ceruti, P.O., 1999, 'Crushed rock and clay amelioration of a nutrient deficient, sandy soil of Maputaland', MSc thesis, Dept. of Geological Sciences, University of Cape Town.

Chao, A., Chazdon, R.L., Colwell, R.K. \& Shen, T.J., 2006, 'Abundance-based similarity indices and their estimation when there are unseen species in samples', Biometrics 62, 361-371. https://doi.org/10.1111/j.1541-0420.2005.00489.x

Chao, A., Colwell, R.K., Lin, C.W. \& Gotelli, N.J., 2009, 'Sufficient sampling for asymptotic minimum species richness estimators', Ecology 90, 1125-1133. https://doi.org/ 10.1890/07-2147.1

Chazdon, R.L., 2003, 'Tropical forest recovery: Legacies of human impact and natura disturbances', Perspectives in Plant Ecology, Evolution and Systematics 6, 51-71. https://doi.org/10.1078/1433-8319-00042

Cockle, K.L., Martin, K. \& Drever, M.C., 2010, 'Supply of tree-holes limits nest density of cavity-nesting birds in primary and logged subtropical Atlantic forest', Biological Conservation 143, 2851-2857. https://doi.org/10.1016/j.biocon.2010. 08.002

Colwell, R.K., 2013, EstimateS: Statistical estimation of species richness and shared species from samples (Version 9.1. O. User's guide and application), Compute Software, viewed 16 December 2016, from http://purl.oclc.org/estimates/

Cooper, K.H., 1985, The conservation status of indigenous forests in Transvaal, Natal and OFS, South Africa, Wildlife Society of South Africa, Durban.

Danoff-Burg, J. \& Xu, C., 2008, Measuring biological diversity, viewed 09 December 2016, from http://columbia.edu/itc/cerc/danoff-burg/MBD Links.html/

D’Antonio, C. \& Meyerson L.A., 2002, 'Exotic plant species as problems and solutions in ecological restoration: A synthesis', Restoration Ecology 10, 703-713. https://doi. org/10.1046/j.1526-100X.2002.01051.x

Dearborn, D.C. \& Kark, S., 2010, 'Motivations for conserving urban biodiversity', Conservation Biology 24, 432-240. https://doi.org/10.1111/j.1523-1739.2009. 01328.x

Denslow, J.S., 1995, 'Disturbance and diversity in tropical rain forests: The density effect', Ecological Applications 5, 962-968. https://doi.org/10.2307/2269347

Department of Environmental Affairs (South African), 2016, National Environmental Management: Biodiversity Act (10/2004): Alien and Invasive Species List, 2016, Government notice \#864, Government Gazette 40166 (29 July 2016).

Dickinson, N., 2003, 'Soil degradation and nutrients', in M.H. Wong \& A.D. Brandshaw (eds.), The restoration and management of derelict land: Modern approaches, pp. 50-65, World Scientific Publishing, Toh Tuck Link, Singapore.

Eeley, H.A., Lawes, M.J. \& Piper, S.E., 1999, 'The influence of climate change on the distribution of indigenous forest in KwaZulu-Natal, South Africa', Journal of Biogeography 26, 595-617. https://doi.org/10.1046/j.1365-2699.1999.00307.x

Environmental Geographic Information Systems (EGIS), 2016, Environmental geographic information systems, Department of Environmental Affairs (DEA) and the Committee on Spatial Information (CSI) (2016), viewed 21 November 2017, from http://www. egis.environment.gov.za/

Fahrig, L., 2003, 'Effects of habitat fragmentation on biodiversity', Annual Review of Ecology, Evolution, and Systematics 34, 487-515. https://doi.org/10.1046/j.13652699.1999.00307x

Flohre, A., Fischer, C., Aavik, T., Bengtsson, J., Berendse, F., Bommarco, R. et al., 2011 'Agricultural intensification and biodiversity partitioning in European landscapes comparing plants, carabids, and birds', Ecological Applications 21, 1772-1781. https://doi.org/10.1890/10-0645.1

Frelich, L.E. \& Lorimer, C.G., 1991, 'Natural disturbance regimes in hemlock-hardwood forests of the upper Great Lakes region', Ecological Monographs 61, 145-164. https://doi.org/10.2307/1943005

Gaugris, J.Y. \& Van Rooyen, M.W., 2008, 'A spatial and temporal analysis of Sand Forest tree assemblages in Maputaland, South Africa', South African Journal of Wildlife Research 38, 171-184. https://doi.org/10.3957/0379-4369-38.2.171 
Gentry, A.H., 1982, 'Patterns of neotropical plant species diversity', in M.K. Hecht, B. Wallace \& G.T. Prance (eds.), Evolutionary biology, pp. 1-84, Springer, Boston, MA

Gibson, L., Lee, T.M., Koh, L.P., Brook, B.W., Gardner, T.A., Barlow, J. et al., 2011 'Primary forests are irreplaceable for sustaining tropical biodiversity', Nature 478 378-381. https://doi.org/10.1038/nature10425

Good, R., 1974, The geography of the flowering plants, Longman Publishing, London.

Gotelli, N.J. \& Colwell, R.K., 2001, 'Quantifying biodiversity: Procedures and pitfalls in the measurement and comparison of species richness', Ecology Letters 4, 379-391. https://doi.org/10.1046/j.1461-0248.2001.00230.x

Griffiths, M.E. \& Lawes, M.J., 2006, 'Biogeographic, environmental, and phylogenetic influences on reproductive traits in subtropical forest trees, South Africa', Ecography 29, 614-622. https://doi.org/10.1111/j.0906-7590.2006.04657.x

Hahs, A.K., McDonnell, M.J., McCarthy, M.A., Vesk, P.A., Corlett, R.T., Norton, B.A. et al., 2009, 'A global synthesis of plant extinction rates in urban areas', Ecology Letters 12, 1165-1173. https://doi.org/10.1111/j.1461-0248.2009.01372.x

Hammer, Ø., Harper, D. \& Ryan, P., 2001, PAST: Paleontological statistics software package for education and data analysis, Computer Software, viewed 05 December 2016, from http://palaeo-electronica.org/

Hobbs, R.J., Arico, S., Aronson, J., Baron, J.S., Bridgewater, P., Cramer, V.A. et al., 2006 Novel ecosystems: Theoretical and management aspects of the new ecological world order', Global Ecology and Biogeography 15, 1-7. https://doi.org/10.1111/ j.1466-822X.2006.00212.x

Hobbs, R.J., Higgs, E. \& Harris, J.A., 2009, 'Novel ecosystems: Implications for conservation and restoration', Trends in Ecology \& Evolution 24, 599-605. https:// doi.org/10.1016/j.tree.2009.05.012

Huang, Y., Ma, Y., Zhao, K., Niklaus, P.A., Schmid, B. \& He, J.-S., 2017, 'Positive effect of tree species diversity on litterfall quantity and quality along a secondary successional chronosequence in a subtropical forest', Journal of Plant Ecology 10 28-35. https://doi.org/10.1093/jpe/rtw115

Jackson, M.M., Turner, M.G., Pearson, S.M. \& Ives, A.R., 2012, 'Seeing the forest and the trees: Multilevel models reveal both species and community patterns', Ecosphere 3, 1-16. https://doi.org/10.1890/ES12-00116.1

Kambaj, O., Sershen \& Ramdhani, S. 2016, 'Forest conservation in a changing climate: Reflections from KwaZulu-Natal', Veld \& Flora 102, 26-29.

Kirkwood, D. \& Midgley, J., 1999, 'The floristics of sand forest in northern KwaZuluNatal, South Africa', Bothalia 29, 293-304. https://doi.org/10.4102/abc.v29i2.602

Koleff, P., Gaston, K.J. \& Lennon, J.J., 2003, 'Measuring beta diversity for presenceabsence data', Journal of Animal Ecology 72, 367-382. https://doi.org/10.1046/ j.1365-2656.2003.00710.x

Kruskal, J.B., 1964, 'Multidimensional scaling by optimizing goodness of fit to a nonmetric hypothesis', Psychometrika 29, 1-27. https://doi.org/10.1007/ BF02289565

Lawes, M.J., Joubert, R., Griffiths, M.E., Boudreau, S. \& Chapman, C.A., 2007, 'The effect of the spatial scale of recruitment on tree diversity in Afromontane forest fragments', Biological Conservation 139, 447-456. https://doi.org/10.1016/j.biocon. 2007.07.016

Lehman, C.L. \& Tilman, D., 2000, 'Biodiversity, stability, and productivity in competitive communities', The American Naturalist 156, 534-552. https://doi.org/10.1086/ 303402

Low, B. \& Rebelo, A., 1996, Vegetation of South Africa, Lesotho and Swaziland: A companion to the vegetation map of South Africa, Lesotho and Swaziland Department of Environmental Affairs and Tourism, Pretoria.

Lugo, A.E. \& Helmer, E., 2004, 'Emerging forests on abandoned land: Puerto Rico's new forests', Forest Ecology and Management 190, 145-161. https://doi. org/10.1016/j.foreco.2003.09.012

MacArthur, R. \& Wilson, E., 1967, The theory of island biogeography, Princeton University Press, Princeton, NJ.

Macdonald, I.A., Loope, L.L., Usher, M.B. \& Hamann, O., 1989, 'Wildlife conservation and the invasion of nature reserves by introduced species: A global perspective', in J.A. Drake \& H.A. Mooney (eds.), Biological invasions: A global perspective, pp. 215-55, Wiley, New York.

Magurran, A., 2004, Measuring biological diversity, Blackwells, Oxford, UK.

Martin, P.H., Canham, C.D. \& Marks, P.L., 2009, 'Why forests appear resistant to exotic plant invasions: Intentional introductions, stand dynamics, and the role of shade tolerance', Frontiers in Ecology and the Environment 7, 142-149. https://doi. org/10.1890/070096

Matlack, G.R., 1994, 'Vegetation dynamics of the forest edge - Trends in space and successional time', Journal of Ecology 82, 113-123. http://www.jstor.org/stable/ 2261391

Matthews, W.S., Van Wyk, A.E., Van Rooyen, N. \& Botha, G.A., 2001, 'Vegetation of the Tembe Elephant Park, Maputaland, South Africa', South African Journal of Botany 67, 573-594. https://doi.org/10.1016/S0254-6299(15)31188-1

Midgley, J., Cowling, R., Seydack, A. \& Van Wyk, G., 1997, 'Forest', in R.M. Cowling, D.M. Richardson \& S.M. Pierce (eds.), Vegetation of southern Africa, pp. 278-299, Cambridge University Press, Cambridge.

Milberg, P. \& Lamont, B.B., 1995, 'Fire enhances weed invasion of roadside vegetation in southwestern Australia', Biological Conservation 73, 45-49. https://doi. org/10.1016/0006-3207(95)90061-6

Moll, E., 1972, 'The current status of mistbelt mixed Podocarpus forest in Natal', Bothalia 10, 595-598. https://doi.org/10.4102/abc.v10i4.1569

Moll, E. \& Cooper, K., 1966, 'Hlogwene Forest (report by the Natal Fieldwork Section)', African Wildlife 20, 326.
Moll, E. \& White, F., 1978, 'The Indian Ocean Coastal Belt', in M.J.A. Werger \& A.C. Van Bruggen (eds.), Biogeography and ecology of southern Africa, pp. 561-598, Dr. W. Junk b.v. Publishers, The Hague.

Morgenthal, T. \& Cilliers, S., 1999, 'Vegetation analysis of Pedlar's Bush, Mpumalanga, and its conservation', South African Journal of Botany 65, 270-280. https://doi. org/10.1016/S0254-6299(15)30994-7

Moro, M.F., de Sousa, D.J.L. \& Matias, L.Q., 2014, 'Rarefaction, richness estimation and extrapolation methods in the evaluation of unseen plant diversity in aquatic ecosystems', Aquatic Botany 117, 213-251. https://doi.org/10.1016/j.aquabot. 2014.04.006

Mucina, L., Adams, J.B., Knevel, I.C., Rutherford, M.C., Powrie, L.W., Bolton, J.J. et al., 2006, 'Coastal vegetation of South Africa', in L. Mucina \& M.C. Rutherford (eds.), The vegetation of South Africa, Lesotho and Swaziland, pp. 658-697, Strelitzia 19, South African National Biodiversity Institute, Pretoria.

Mucina, L. \& Geldenhuys, C.J., 2006, 'Afrotemperate, subtropical and azonal forests', in L. Mucina \& M.C. Rutherford (eds.), The vegetation of South Africa, Lesotho and Swaziland, pp. 585-608, Strelitzia 19, South African National Biodiversity Institute, Pretoria.

Mucina, L. \& Rutherford, M., 2006, The vegetation of South Africa, Lesoto and Swaziland, Strelitzia 19, South African National Biodiversity Institute, Pretoria.

Nel, J., Richardson, D., Rouget, M., Mgidi, T., Mdzeke, N., Le Maitre, D. et al., 2004 'Proposed classification of invasive alien plant species in South Africa: Towards prioritizing species and areas for management action', South African Journal of Science 100, 53-64, viewed 19 June 2017, from http://hdl.handle.net/10520/ EJC96213

Newbold, T., Hudson, L.N., Phillips, H.R., Hill, S.L., Contu, S., Lysenko, I. et al., 2014, 'A global model of the response of tropical and sub-tropical forest biodiversity to anthropogenic pressures', Proceedings of the Royal Society of London B: Biological Sciences 281, 1-10. https://doi.org/10.1098/rspb.2014.1371

Olivier, P.I. \& Van Aarde, R.J., 2014, 'Multi-scale sampling boosts inferences from beta diversity patterns in coastal forests of South Africa', Journal of Biogeography 41 1428-1439. https://doi.org/10.1111/j.1365-2486.2008.01540.x

Pimm, S.L., Jenkins, C.N., Abell, R., Brooks, T.M., Gittleman, J.L., Joppa, L.N. et al. 2014, 'The biodiversity of species and their rates of extinction, distribution, and protection', Science 344, 1-12. https://doi.org/10.1126/science.1246752

Pooley, B., 1998, A field guide to wild flowers of KwaZulu-Natal and the eastern region, Natal Flora Publications Trust, Durban.

Richardson, D.M., Rouget, M., Ralston, S.J., Cowling, R.M., Van Rensburg, B.J. \& Thuiller, W., 2005, 'Species richness of alien plants in South Africa: Environmental correlates and the relationship with indigenous plant species richness', Ecoscience 12, 391-402. https://doi.org/10.2980/i1195-6860-12-3-391.1

Rodriguez, L.F., 2006, 'Can invasive species facilitate native species? Evidence of how, when, and why these impacts occur', Biological Invasions 8, 927-939. https://doi. org/10.1007/s10530-005-5103-3

Rutherford, M.C., Mucina, L., Powrie, L.W., Mucina, L. \& Rutherford, M., 2006, 'Biomes and bioregions of southern Africa', in L. Mucina \& M.C. Rutherford (eds.), The vegetation of South Africa, Lesotho and Swaziland, pp. 30-51, Strelitzia 19, South African National Biodiversity Institute, Pretoria.

Rutherford, M.C. \& Westfall, R. (eds.), 1994, Biomes of southern Africa: An objective categorization, National Botanical Institute, Pretoria.

Scott-Shaw, C. \& Escott, B. 2011, KwaZulu-Natal provincial pre-transformation vegetation type map-2011, Ezemvelo KZN Wildlife, Durban (Unpublished GIS Coverage Report; kznveg05v2 011 wll.zip).

South African National Biodiversity Institute (SANBI), 2018a, New Plants of southern Africa: southern African plant names and floristic details, viewed 17 June 2018, from http://posa.sanbi.org/

South African National Biodiversity Institute (SANBI), 2018b, Red list of South African plants, viewed 06 February 2018, from http://redlist.sanbi.org/

Steenkamp, Y., Van Wyk, B., Victor, J., et al., 2004, 'Maputaland-Pondoland-Albany', in R.A. Mittermeier, P. Robles Gil, M. Hoffmann, J. Pilgrim, T. Brooks, C.G. Mittermeier, J. Lamoreux \& G.A.B. Da Fonseca (eds.), Hotspots revisited: earth's biologically richest and most endangered ecoregions, pp. 219-228, CEMEX, Mexico City.

Ter Steege, H., Pitman, N.C., Phillips, O.L., Chave, J., Sabatier, D., Duque, A. et al., 2006 'Continental-scale patterns of canopy tree composition and function across Amazonia', Nature 443, 444-447. https://doi.org/10.1038/nature05134

Terborgh, J. \& Andresen, E., 1998, 'The composition of Amazonian forests: Patterns at local and regional scales', Journal of Tropical Ecology 14, 645-664. https://doi. org/10.1017/S0266467498000455

Untiedt, S., 1992, 'Mtunzini: Profile of a recreation town', Honours thesis, Geography and Environmental Studies, University of Zululand, Kwadlangezwa, South Africa (Unpublished).

Uriarte, M., Canham, C.D., Thompson, J., Zimmerman, J.K., Murphy, L., Sabat, A.M et al., 2009, 'Natural disturbance and human land use as determinants of tropical forest dynamics: Results from a forest simulator', Ecological Monographs 79, 423-443. https://doi.org/10.1890/08-0707.1

Van Aarde, A.M. \& Claassens, R., 1998, 'Soil characteristics of rehabilitating and unmined coastal dunes at Richards Bay, KwaZulu-Natal, South Africa', Restoration Ecology 6, 102-110. https://doi.org/10.1046/j.1526-100x.1998.06113.x

Van Aarde, R., Wassenaar, T., Niemand, L., Knowles, T. \& Ferreira, S., 2008, 'Coastal dune forest rehabilitation: A case study on rodent and bird assemblages in northern KwaZulu-Natal, South Africa', in M.L. Martínez \& N.P. Psuty (eds.), Coastal dunes, pp. 103-115, Springer Publishing, Berlin, Germany. 
Van Wyk, A.E. \& Smith, G.F., 2001, Regions of floristic endemism in southern Africa: $A$ review with emphasis on succulents, Umdaus Press, Pretoria.

Van Wyk, B. \& Van Wyk, P., 1997, Field guide to trees of southern Africa, Struik, Cape Town.

Van Wyk, G.F., Everard, D.A., Midgley, J.J. \& Gordon, I.G., 1996, 'Classification and dynamics of southern African subtropical coastal lowland forest', South African Journal of Botany 62, 133-142. https://doi.org/10.1016/S0254-6299(15)30612-8

Von Maltitz, G., Mucina, L., Geldenhuys, C.J., Lawes, M., Eeley, H., Adie, H. et al., 2003 Classification system for South African indigenous forests: An objective classification for the Department of Water Affairs and Forestry, Environmentek, Pretoria (Report no. ENV-PC 17:1-284).

Wassenaar, T., Van Aarde, R., Pimm, S. \& Ferreira, S., 2005, 'Community convergence in disturbed subtropical dune forests', Ecology 86, 655-566. https://doi.org/10. 1890/03-0836
Weeds and Invasive Plants (WIP), 2016, Weeds and Invasive Plants: An online checklist, viewed 21 October 2016, from http://agis.agric.za/wip/

White, P.S., 1979, 'Pattern, process, and natural disturbance in vegetation', Botanical Review 45, 229-299, viewed 13 February 2017, from http://labs.bio.unc.edu/ white/Reprints/White\%201979.pdf

Whittaker, R.H., 1972, 'Evolution and measurement of species diversity', Taxon 21, 213-251. https://doi.org/10.2307/1218190

Whittaker, R.J., Willis, K.J. \& Field, R., 2001, 'Scale and species richness: Towards a general, hierarchical theory of species diversity', Journal of Biogeography 28, 453-470. https://doi.org/1365-2699.2001.00563.x

Zhang, J. \& Cao, M., 1995, 'Tropical forest vegetation of Xishuangbanna, SW China and its secondary changes, with special reference to some problems in local nature conservation', Biological Conservation 73, 229-238. https://doi.org/10.1016/ 0006-3207(94)00118-A 